\title{
Jalal's Angels of Deliverance and Destruction: Genealogies of Theo-politics, Sovereignty and Coloniality in Iran and Israel - CORRIGENDUM
}

\author{
Eskandar Sadeghi-Boroujerdi ${ }^{1 \star}$ and Yaacov Yadgar $^{2}$ \\ ${ }^{1}$ Goldsmiths, University of London and ${ }^{2}$ St Anne's College, University of Oxford \\ ${ }^{\star}$ Corresponding author. E-mail: E.Sadeghi@gold.ac.uk
}

In the above article an incorrect sentence stating that Jalal Al-e Ahmad was arrested and condemned to prison without trial following the 1953 coup was published.

The sentence on page two should instead say:

"Al-e Ahmad was not condemned to serve any prison time in the aftermath of the 1953 coup, but he was arrested, briefly detained and released soon thereafter."

The author apologises for this error.

\section{Reference}

Sadeghi-Boroujerdi E and Yadgar Y (2019). Jalal's Angels of Deliverance and Destruction: Genealogies of Theo-politics, Sovereignty and Coloniality in Iran and Israel. Modern Intellectual History 1-25. https:// doi.org/10.1017/S1479244319000222

Cite this article: Sadeghi-Boroujerdi E, Yadgar Y (2021). Jalal's Angels of Deliverance and Destruction: Genealogies of Theo-politics, Sovereignty and Coloniality in Iran and Israel - CORRIGENDUM. Modern Intellectual History 18, 298-298. https://doi.org/10.1017/S1479244320000244

(c) The Author(s) 2020. Published by Cambridge University Press 